Review

\title{
Understanding the Key Quality Factors in Construction Projects-A Systematic Literature Review
}

\author{
Sławomir Wawak ${ }^{1, *(D)}$, Žanesa Ljevo ${ }^{2}$ (D) and Mladen Vukomanović ${ }^{3}$ (D) \\ 1 Management Process Department, Cracow University of Economics, 31510 Cracow, Poland \\ 2 Faculty of Civil Engineering, University of Sarajevo, 71000 Sarajevo, Bosnia and Herzegovina; \\ zanesa.ljevo@gf.unsa.ba \\ 3 Faculty of Civil Engineering, University of Zagreb, 10000 Zagreb, Croatia; \\ mladen.vukomanovic@grad.unizg.hr \\ * Correspondence: wawaks@uek.krakow.pl
}

Received: 23 November 2020; Accepted: 9 December 2020; Published: 11 December 2020

check for updates

\begin{abstract}
Project management frameworks describe the preferred approaches to project quality management, as well as applicable methods and tools. Despite this, quality problems in the construction project are still widespread. This study aimed to identify crucial quality-related factors in construction project management and find relations between them, to help researchers and project managers better respond to quality issues. A systematic literature review (SLR) was used to identify previous studies on quality-related factors. Literature review and further quantitative analysis revealed that quality-related factors are related to three categories: Quality of project process, quality of organisational processes, and quality of results (products), which together create the quality of the whole construction project. The results highlight quality-related factors (14 related to the quality of processes, 6 to quality of an organisation, and 13 to quality of products) that should be taken into account in further research, as well as planning and executing construction projects. Their inclusion at the planning stage should help project managers, sponsors, and steering committees avoid or minimise quality-related problems. Moreover, this study sheds an interesting light on quality. We found that the quality of processes and quality of an organisation has precedence over the final product quality. Based on the results of the study, structural equation modelling (SEM) was used to create a null model that will be the starting point for further research in the construction enterprises.
\end{abstract}

Keywords: quality management; project management; systematic literature review; factors

\section{Introduction}

Construction companies have to improve their competitiveness continuously, in order to achieve success in the market, and it is possible mainly through better performance of construction projects. For many years success of that kind of project was associated with high-quality material products. In recent years that approach was also extended to accompanying services. For example, the Standish Group report defines the project's success as delivering some construction and customer satisfaction and high return on value to the organisation [1]. According to that report, only $14 \%$ of projects are successful, $67 \%$ —challenged, and as much as $19 \%$ are unsuccessful.

Nowadays, the majority of standards are oriented on procedures and processes such as PRINCE2 and MSP by Axelos, PMBoK by PMI [2-4]. Furthermore, there are many studies about project management, quality management, process, project life cycle, project products, and stakeholders requirements in the literature. Even though there is a vast spectrum of literature written on project 
management (PM) standards [5-7], there were only a few research results concerning the relations between them. Some studies on project management are analysed from the international perspective of project management development. Modern project management processes have to be adaptable, and an experimental approach to the project cycle should be taken in many cases. The current project management practice is questioned in the scientific literature on project management due to insufficient effectiveness and efficiency. Authors offer new approaches to processes combining empirical research with theoretical insights. The business environment becomes complicated, and rapid changes require a creative approach to project management processes $[8,9]$. The other literature trend highlights the impact of the quality management system on cost-saving and making processes more efficient $[10,11]$. Multiple authors refer to the life cycle management's significant role in the construction, project quality management (as a general idea), cost management, and schedule management [12]. Important areas of study in construction project management are the wastages and defects during work, which are caused by low quality. Up to $40 \%$ of the poorly managed construction enterprise's revenues can be spent on low quality. Studies suggest that the teamwork and the implementation of quality management systems could help lower those costs [13].

In project management, the quality of results should be treated as a relation between the requirements and needs of customers and what was delivered by the project team [14]. To fully understand that relationship, the delivery should be treated and analysed as a process, including its dynamics, not only as a static element.

Many factors related to the external environment and the company's internal units affect any modern enterprise performance. For a long time, the compliance of products with technical documentation and contractual specifications has been considered sufficient for their quality. In the same manner, the fulfilment of project requirements should result in high project quality. However, the modern approach to quality issues led to the finding that the project's final quality is often determined not only by the sole results, but also by how those results were achieved. Ron Basu defined three aspects of project quality: Product quality, quality of management processes, and quality of the organisation, i.e., leadership, skills, and communication [15]. Therefore, every company and project team needs to improve the efficiency and effectiveness of processes to respond correctly and promptly to changing market challenges [16]. In the case of projects, one of the ways it can be achieved is by implementing and improving the quality management process [17]. There are multiple studies on the implementation and improvement of quality management in organisations and projects. However, they are not clear about evaluating the impact of the quality on final project results. Some authors have proposed measures. However, to this date, there was no systematic approach to the measurement of the relationship between project quality management and project results quality. For example, Doskocil and Lacko identified sustainability project's critical success factors [18], while $\mathrm{Wu}$, Zhao, and Ma described factors related to green construction management [19]. The most advanced approach was proposed by Wang et al., who used the European Foundation for Quality Management (EFQM) model criteria to evaluate construction projects from the maturity point of view [20]. Later on, Vukomanović et al. [21] proved that the EFQM model's criteria weights do not entirely correspond with how quality is achieved within the construction processes (mainly in projects) and how the end-user and society perceive it. Therefore, it remained unclear how quality is conceived and delivered within construction project-oriented processes. Ljevo, Vukomanović and Džebo [22] found the relation between quality factors of the project management process and products throughout the definition and planning projects phase. Still, it did not include the organisation's quality factors, but only the project ones, not considering the influence of organisational factors.

Earlier studies and the literature review show that the quality of the final project product can be monitored through the organisational and processual quality factors. Finding relations between those factors can help project managers to identify a potential quality problem at the early stage of project implementation. The authors found no previous SLRs on quality-related factors in construction project management as a significant gap in the current body of knowledge. The lack of a systemic approach to 
hidden quality factors prevents decision-makers from making decisions with full awareness of their effects. It can also lead to fragmentary analyses that do not explain the essence of the construction industry quality problems. Given this background, the SLR is an essential and necessary step allowing to complete understanding of the field of study. The study should help answer the following questions:

- What are the quality-related factors identified covering issues of quality management in construction projects?

- What are the relations between factors of organisation, project and product?

According to this, we defined the following objectives:

- Identification of quality-related factors in construction projects present in the literature and their grouping.

- Comparison of the obtained results by reviewing the literature and previous studies of the authors.

- Construction of the preliminary model showing assumed relations between groups of factors.

This study contributes to the field of project management and quality management in several ways. First, we provide critical long-term analysis of previously published papers. As we found no previous SLRs on quality management in project management published in recognised journals, the results of our research can be used by other authors as a starting point for more in-depth analyses of this field of study. Second, we present organisational, processual, and product-related quality factors essential in construction projects. Quality is often associated with project managers and even researchers with the final results of the project. Third, we offer a framework for quantitative studies on relations between those factors. Furthermore, the results of this study can be used as an input to further development of process-based project management standards, such as PRINCE2 and MSP by Axelos, PMBoK by PMI. This study serves on the one hand as a presentation of partial results, but on the other, it opens a discussion that will help authors to improve the next stage of the research project.

Its results will help participants' different managerial perspectives from investors, project managers, designers, consultants, contractors, supervisors in construction projects to understand the organisational, processual, and product-related quality factors more clearly.

Finally, the study adopts the post-positivist position of critical realism, where the reality exists independently of the researcher. The interpretation of the nature of reality requires the researcher to recognise and minimise biases [23].

The paper is organised as follows. In the next section, we present steps of an SLR methodology. We present a descriptive analysis that covers identified regularities and trends in studied papers. After that, we present the results obtained through the analysis and compare them with the previous author's study. Then we present preliminary null scanning electron microscopy (SEM) model that results from this study.

\section{Sources and Methods}

\subsection{Systematic Literature Review}

SLR is an exact and reproducible method for identification, evaluation, and interpretation of predefined fields of study. Researchers use it for summarising previous studies, as well as establish a framework for future research $[24,25]$. The approach is particularly suitable when the analysed subject is fragmented across fields of study, as in quality management in construction project management [26].

The literature review process is performed according to predefined steps and search strategy, which increases transparency, reproducibility, and quality of results. That can be further improved using a standardised approach proposed in PRISMA (Preferred Reporting Items for Systematic Reviews and Meta-Analyses). The PRISMA statement consists of a checklist covering all critical issues that should be reported and a flow diagram that presents the research procedure [27]. The paper adopts the PRISMA statement to avoid errors and bias and provide high-quality results. 


\subsection{Research Procedure}

The SLR approach is consistent with suggestions made by [26]. It is compatible with PRISMA method and includes the following steps:

- identification of studies,

- title, abstract and keywords screening,

- full-text screening,

- analysis of included papers,

- definition of a null SEM model,

- discussion of the results and their comparison with previous research.

In the first step, the search criteria were established and applied. The search was limited to peer-reviewed papers in English that were published in recognised journals or proceedings listed in Scopus or Web of Science databases. These databases provide complementary bibliographic information. Additionally, a snowball approach was applied in step three. As no SLR that integrated the findings on quality management in managing construction projects was performed, we decided to adopt a long-term approach. The oldest paper found was published in 1983 and the latest in 2019. The search rule applied to titles, abstracts and keywords were: "project management" AND "quality management". Due to the way the databases work, that rule also covered: "quality" AND "project management" as well as "quality management" AND "project". No further criteria were defined to limit the impact of classification errors in the databases, which increased effort in the following steps, but at the same time, it increased the quality of results.

The screening was divided into two stages. In stage 1, the authors focused on the relevance of papers. The adopted criterion was raising the topic of quality management in project management. Even though the keywords "quality management" and "project management" were defined in the papers. They were used in some cases despite a faint relationship with the content. In stage 2, the authors focused on fields of study covered in the papers.

Both stages of screening were performed using spreadsheets and data imported from databases in CSV files. Apart from default fields offered by Scopus and Web of Science, e.g., authors, title, year of publication, source title, abstract, keywords, additional codes were defined to help achieve the objectives of this study. These include industry, country, used methodology, number of objects in research, project management category, quality management category, described methods, findings, identified gaps, and quality factors related to organisation, process, and product.

In the next step, papers were read, and screening was performed based on the full-texts of papers. Full-texts were downloaded from databases authors were eligible to (EBSCO, Science Direct, Emerald, JSTOR, Wiley, and Academia, Research Gate, Google Scholar). The whole process is presented on Figure 1.

This study leans on the prior research the authors did in Croatia, Bosnia and Herzegovina. Through the questionnaire, the participants evaluated factor's importance according to the Likert scale, 154 professionals contributed to the final list of quality factors at different project stages. Further information about the research can be found in the paper analysing the significance of critical quality factors for the management of construction projects [28].

The last step of this study was defining a null SEM model, which is an entry point for the following parts of the research project mentioned above. SEM is defined as a statistical approach that takes a confirmatory approach to the analysis of structural theory [29]. Based on this approach, the studied phenomenon can be conceptualised more clearly by highlighting causal relationships between its parts. The results can be tested, and the consistency of the model can be determined. Like some other multivariate techniques, SEM is not limited to the analysis of only a single relationship at one time. It provides a mechanism for the simultaneous examination of multiple dependent relationships [30]. SEM was already used by researchers studying factors affecting quality, e.g., S. Hussain et al. studied factors affecting the quality of social infrastructure projects [31]. That approach has some limitations. 
However, the authors strive to overcome them by using a set of different quantitative and qualitative methods throughout the whole research project.

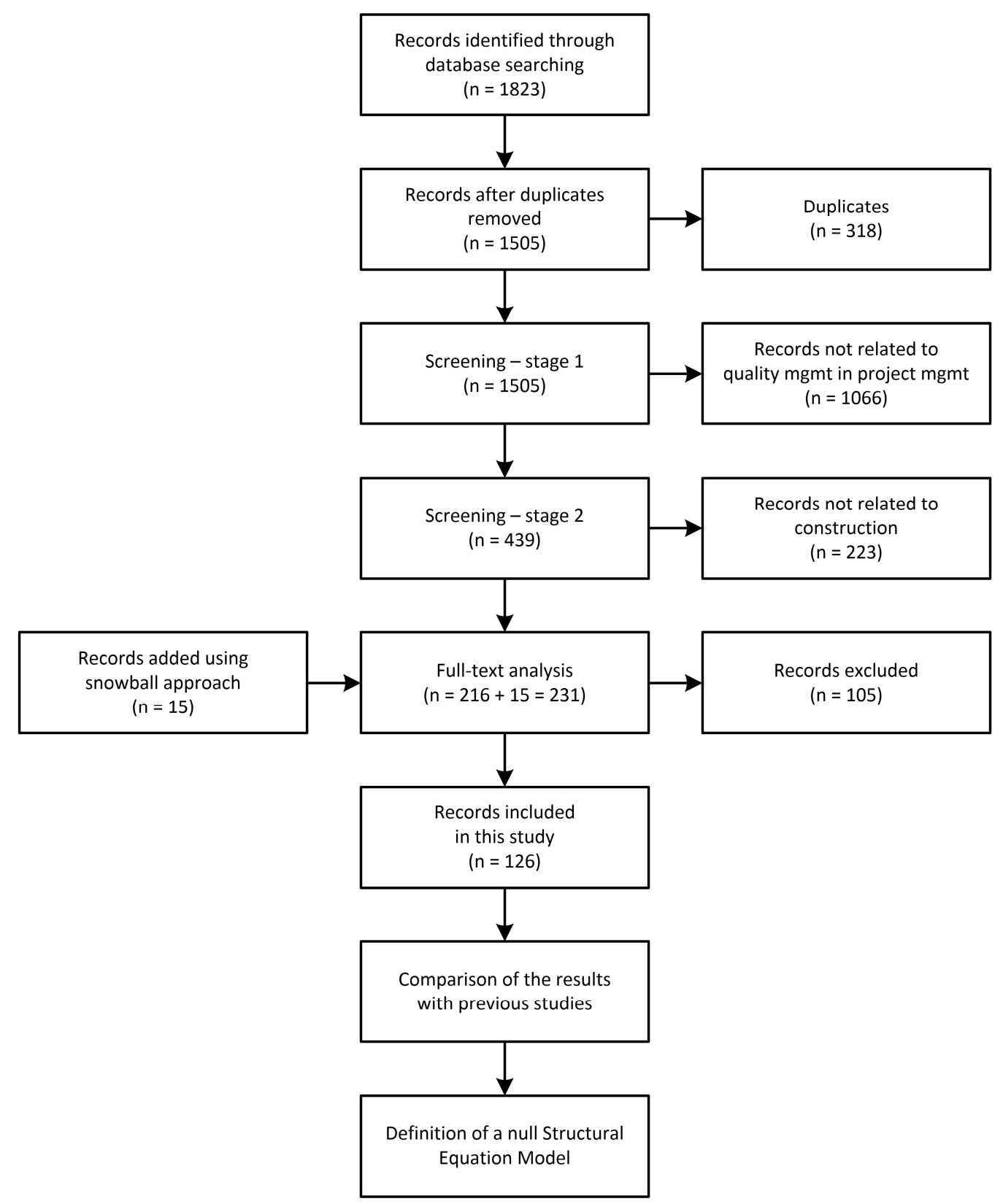

Figure 1. Flow diagram of the SLR and the analysis process. Source: research results.

\subsection{Descriptive Analysis}

The descriptive analysis of included papers should lead to a reduction of content into codes and identification of the emerging patterns. That allowed us to find regularities and trends in studies on quality management in construction project management. Construction project management and quality management are popular fields of study. However, not many authors study both of them simultaneously. The papers included in this study were published in 61 journals or peer-reviewed conference publications. There is no one leading journal covering that topic. The period of the study was over 30 years. Those are the causes of the widespread of papers across journals. A list of the most popular journals was presented in Table 1. 
Table 1. List of the most popular journals.

\begin{tabular}{cc}
\hline Journal Title & Papers \\
\hline Journal of Management in Engineering & 17 \\
Construction Management and Economics & 14 \\
Journal of Construction Engineering and Management & 9 \\
International Journal of Project Management & 8 \\
Applied Mechanics and Materials & 6 \\
International Journal of Productivity and Quality Management & 3 \\
Procedia Engineering & 3 \\
Total Quality Management & 3 \\
TQM Magazine & 3 \\
Advanced Materials Research & 2 \\
Automation in Construction & 2 \\
Building and Environment & 2 \\
Engineering, Construction and Architectural Management & 2 \\
Journal of Professional Issues in Engineering Education and Practice & 2 \\
Others & 50 \\
\hline
\end{tabular}

Source: research results.

In the case of 112 papers, we were able to determine the country where studies were performed. The information was either presented by authors or found based on affiliation. We found 32 countries, with the largest number of papers in the USA (22), China (16), UK (13), and Malaysia (9). Papers grouped by continents and years of publication present how the idea of quality management in construction project management spread throughout the world (Figure 2). It is not surprising that the first English publications were found in North America, then in Europe, and later in Asia and Australia, as the ideas of quality management and project management have spread similar way.

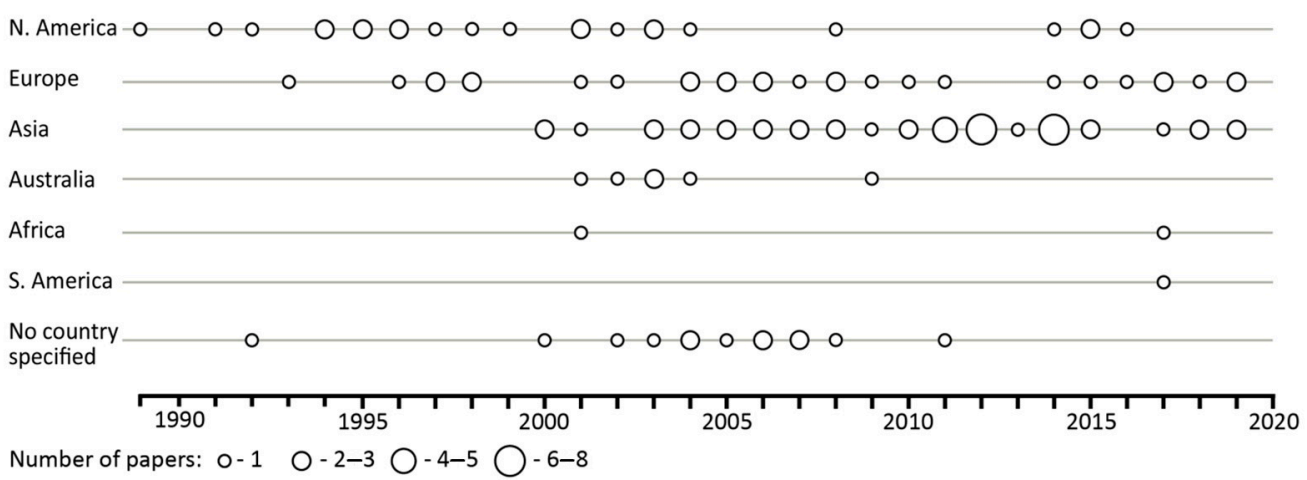

Figure 2. Number of publications by year and continent. Source: research results.

The most popular methods used by researchers were: Surveys (42), literature-based considerations (35) and case studies (31). Other methods used were: literature review, document analyses, interviews, statistical analyses and observation (Figure 3).

Each paper, based on full-text analysis, was classified into one of the categories. Further analysis allowed us to define groups of categories and present the popularity of specific categories in the timespan of the study. Categories that contained only one paper were removed. Therefore, in Table 2, only 121 papers are presented. Overall, eight groups with 20 categories were found. The most popular subjects covered in the papers were performance issues in projects, system approach to project quality management, costs of quality, and methods. The grey bars on Table 2 present timespans between the first and the last publication in each category. We do not suppose that some categories are no longer studied. The table refers only to the corpus of papers included in this study to better understand its structure. 
Table 2. Number of papers by categories and timespan of their publication.

\begin{tabular}{|c|c|c|c|c|c|c|c|c|c|}
\hline Group & Category & $\mathbf{N}$ & 1990 & 1995 & 2000 & 2005 & 2010 & 2015 & 2020 \\
\hline \multirow{2}{*}{$\begin{array}{l}\text { Organisation quality } \\
\text { management related }\end{array}$} & Quality culture & 9 & & & & & & & \\
\hline & $\begin{array}{l}\text { Process vs. } \\
\text { organisation }\end{array}$ & 2 & & & & & & & \\
\hline \multirow{2}{*}{ Quality Management System } & QMS & 13 & & & & & & & \\
\hline & $\begin{array}{l}\text { QMS } \\
\text { implementation }\end{array}$ & 3 & & & & & & & \\
\hline Satisfaction & $\begin{array}{l}\text { Customer } \\
\text { satisfaction }\end{array}$ & 3 & & & & & & & \\
\hline \multirow{4}{*}{ Performance related } & Performance & 15 & & & & & & & \\
\hline & $\begin{array}{l}\text { Critical Success } \\
\text { Factors }\end{array}$ & 5 & & & & & & & \\
\hline & Quality factors & 3 & & & & & & & \\
\hline & Costs of quality & 10 & & & & & & & \\
\hline \multirow{3}{*}{ Quality Assurance related } & Improvement & 5 & & & & & & & \\
\hline & Quality inspection & 5 & & & & & & & \\
\hline & Rework & 3 & & & & & & & \\
\hline \multirow{3}{*}{ External relations } & Procurement & 6 & & & & & & & \\
\hline & Partnering & 4 & & & & & & & \\
\hline & Suppliers QM & 5 & & & & & & & \\
\hline \multirow{2}{*}{ Other management systems } & Environment & 2 & & & & & & & \\
\hline & Safety & 3 & & & & & & & \\
\hline Methods & Methods & 11 & & & & & & & \\
\hline
\end{tabular}




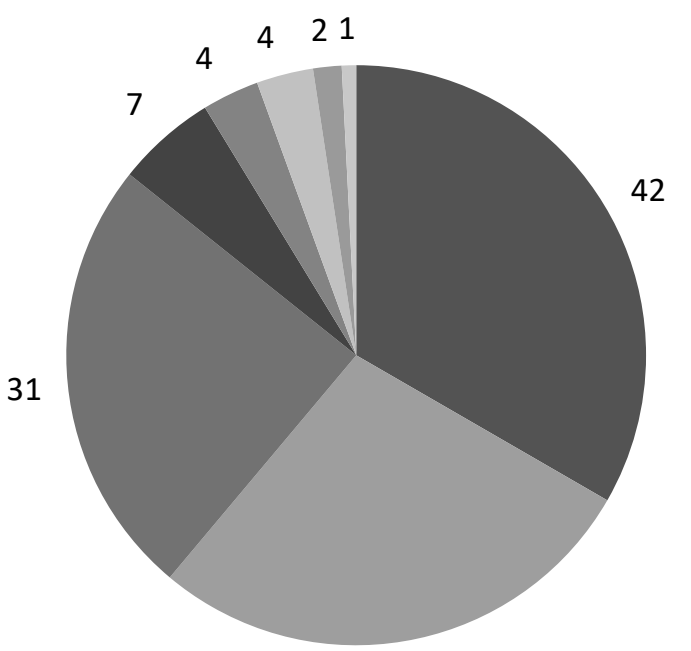

$$
\begin{aligned}
& \text { - survey } \\
& \text { considerations } \\
& \text { n case study } \\
& \text { - literature review } \\
& \text { document analysis } \\
& \text { interviews } \\
& \text { statistical analysis } \\
& \text { observation }
\end{aligned}
$$

35

Figure 3. Methods used by researchers. Source: research results.

The list of papers included in this study was presented in Appendix A. The papers were sorted according to group and category presented in Table 2.

\section{Results}

\subsection{Selection of the Papers}

Overall, 1823 records were identified, of which 318 turned out to be duplicated. Therefore, only 1505 papers were screened.

The causes of papers exclusion in that stage were: title or abstract not related to the subject of this study in 730 records, only quality management covered in 183 papers, 49 papers covered only project management, description of quality management implementation project in 49 papers, 55 are not a paper, e.g., book chapter, editorial, report.

Overall, 1066 records were excluded, and 439 were considered in further steps. We found 216 papers related to construction. Papers related to software (104) or other fields (119) were excluded. Unfortunately, 36 papers were not available in databases: EBSCO, Science Direct, Emerald, JSTOR, Wiley, Academia, Research Gate, Google Scholar.

An analysis of references led to the inclusion of the other 15 papers (snowball approach). According to Kitchenham and Charters [32], quality criteria were defined: enumeration of objectives or questions, description of the methodology, presentation, and discussion of findings. In the results of full-text screening, several papers were excluded. The causes included; not meeting quality criteria (31), content faintly related to the subject of the study (32), duplicated content despite different titles and abstracts (4), retracted papers (2). Overall, 105 papers were excluded. Finally, 126 papers were included in this study (Figure 1).

\subsection{Phases of Construction Projects}

For this research, we chose a five-stage model of the construction project: initiation, planning, execution, monitoring and control, and closure [33]. The most impact on the quality of the project results is performed in the first four phases, while in the last achieved quality can be observed. In this study, the authors attempted to identify critical quality management factors in all construction projects. Only in 54 papers, authors narrowed their study to one or more project phases. In other cases, a different point of view was adopted, e.g., quality management methods or areas. This number includes all papers published before 1995. No papers referring to the closure phase were found, and only a few referred to the initiation phase. The initiation phase can have a significant impact on results quality; however, it is often overlooked by researchers, as that impact is often indirect and difficult to measure. The 
interest in the planning and execution phases was high throughout the whole study period. On average, the planning phase was analysed in $18 \%$ of the paper, while the execution phase in $20 \%$. In phase 4-monitoring and control-we noticed a substantial increase in the number of studies since 2015. A quarter of the papers included in this study and published in the years 2015-2019 covered monitoring and control. The number of papers by project phase and publication year was presented in Figure 4 .

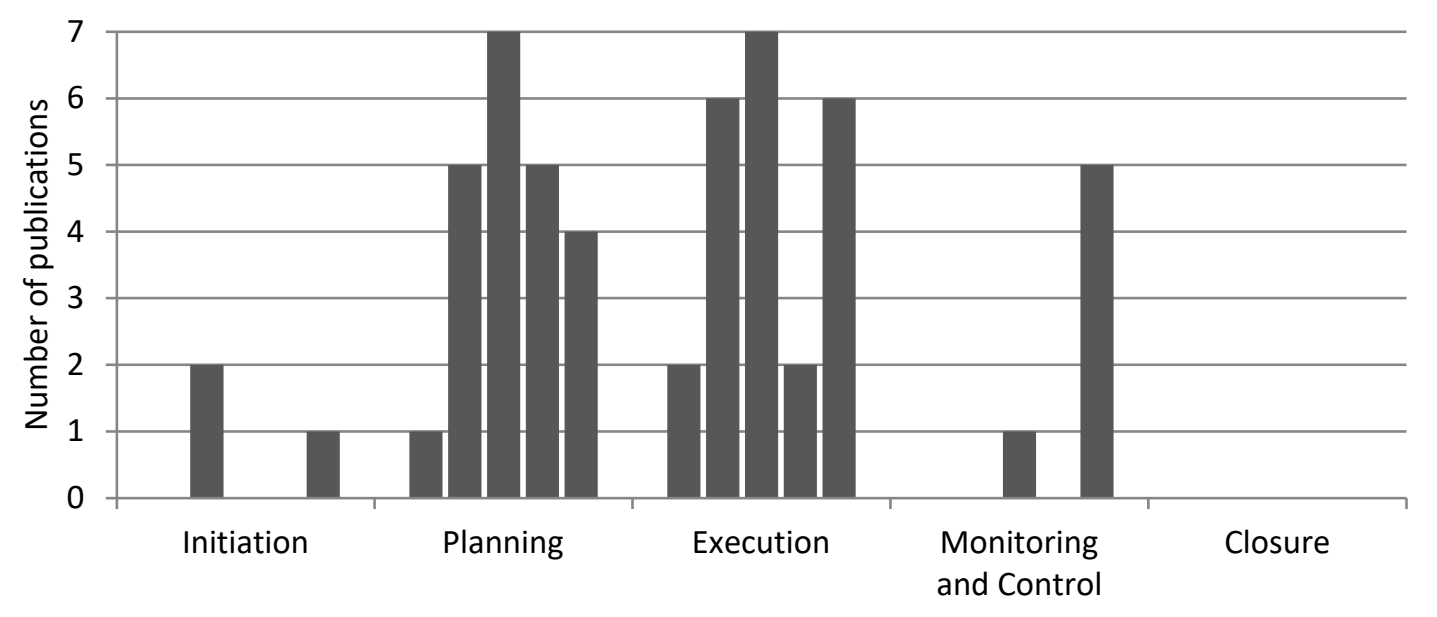

Project phases and publication years

(1995-2019, 5-year periods)

Figure 4. Number of papers by project phase and publication year. Source: research results.

\subsection{Identification of Quality-Related Factors}

The current study revealed the third type of quality factors related to the organisation, as well as several new process-related factors. The most popular group of quality factors is related to processes performed in construction projects. In over $80 \%$ of analysed papers published after 2010 , process quality factors were mentioned and studied. Due to the popularity quality approach based on TQM and ISO 9001, they are well-acquainted by managers and researchers and relatively easy to observe. The second popular type is quality factors related to the product (results). They can be divided into subgroups based on project phases: Initiation, planning, and execution. Over $50 \%$ of papers published after 2005 mentions them. Most of the authors, however, focus on factors occurring in the execution phase. The last group, namely organisational quality factors is related to the organisation's permanent elements that do not change from project to project and form the foundation for efficient quality management in subsequent construction projects. As visible on Figure 5 they are the least popular. However, after 2010 more studies covered them. It should also be noted that $29 \%$ of papers published before 1995 mentioned those factors. Therefore, the importance of permanent organisational structures for quality assurance and management was again appreciated. The drop in the number of publications visible on the figure in the last group (2015-2019) is related to the general decline in the number of papers covering quality management in construction projects in those years. The full list of quality factors was presented in Table 3. Appendix B contains their interpretation given that all factors are self-explanatory. 
Table 3. Quality factors by types.

\begin{tabular}{|c|c|c|}
\hline Process Quality Factors & Organisation Quality Factors & Product Quality Factors \\
\hline & & Phase 1. Initiation \\
\hline F1: Planning and control $\left(29^{*}\right)$ & & S1: Accuracy of specifications (15) \\
\hline F2: Involvement and teamwork (15) & & S2: Transfer without errors and shortcomings (3) \\
\hline F3: $\quad$ Expertise and knowledge (24) & & S3: Downtime (0) \\
\hline F4: Customer satisfaction (8) & & Phase 2. Planning \\
\hline F5: Top management commitment (16) & & Prose 2. F tanting \\
\hline F6: Communication (19) & O1: Quality department (7) & D1: Complete technical documentation (13) \\
\hline F7: Continuous improvement (10) & O2: Long-term partnering (3) & D2: Permits acquired $(0)$ \\
\hline F8: Coordination between project participants (11) & O3: Quality audit (4) & D3: Difference between predicted and planned budgets (1) \\
\hline F9: Quality policy (5) & O4: Clear responsibilities (8) & Phase 3. Execution \\
\hline F10: Availability of resources (9) & O5: Quality culture (4) & E1: Customer satisfaction at the end phase (12) \\
\hline F11: Supplier quality management (23) & O6: Formalisation (9) & E2: The viability of the project (2) \\
\hline Identified in this study: & & E3: Compliance with scope (32) \\
\hline F12: : Quality supervision (11) & & E4: Contribution for future projects $(0)$ \\
\hline F12. Re Ruirements management (9) & & E5: Completion of inspection and use permit (7) \\
\hline F13: Requirements management (9) & & E6: Transfer without errors and shortcomings (9) \\
\hline F14: Health and safety (8) & & E7: Initial budget change (8) \\
\hline
\end{tabular}

* the number of papers mentioning the factor. Interpretation of the factors can be found in Appendix B. Source: research results. 


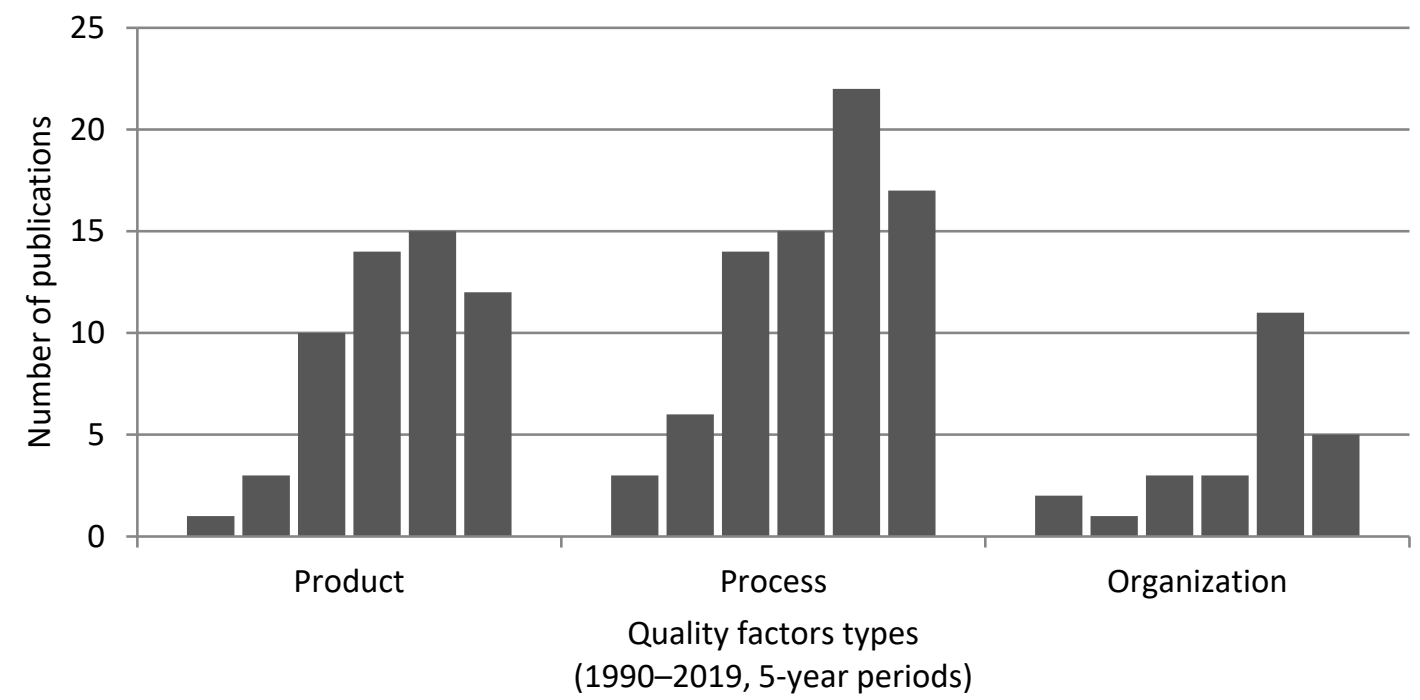

Figure 5. Number of papers describing quality factors by factor type and publication year. Source: research results.

\subsection{Quantitative Description of Quality-Related Factors}

The process quality factors can be observed mainly during the planning and execution phases. The single most often studied factor is F1 "planning and control", which has been increasingly mentioned by authors, even $40 \%$ in recent years. Other factors, which are being studied more and more, are: F5 "top management commitment", F8 "coordination between project participants" and F11 "supplier quality management". Factors of constant and robust interest are: F2 "involvement and teamwork", F3 "expertise and knowledge", F6 "communication" and newly identified F12 "quality supervision". Only in a few papers were mentioned: F4 "customer satisfaction", F9 "quality policy" and F14 "health and safety"; however, in the case of F9, most of the papers were published in recent five years. The most surprising is a low number of papers mentioning F4 "customer satisfaction". That shows a higher focus on technical factors related to quality assurance and lower on soft ones related to quality management, even though many authors refer to TQM philosophy. Customer satisfaction is treated more as a result (factor E1) than part of the process.

The organisation quality factors referring to the permanent structure are essential even in strongly projectized construction companies. They speed up the start of the projects due to the provision of staff, training and procedures. They also can store and share knowledge and lessons learnt between projects. They work in background and are easily omitted. In this study, six factors of this type were identified:

- $\mathrm{O} 1$ "quality department" - permanent manager or department that covers quality issues in multiple projects with own budget,

- $\quad$ O2 "long-term partnering"- - developing long-term cooperation with selected suppliers,

- O3 "quality audit"-monitoring of the project from the company point of view,

- O4 "clear responsibilities" —an unequivocal division of tasks, powers and responsibilities,

- O5 "quality culture" - systematic actions to build an organisational culture based on quality and continuous improvement,

- O6 "formalisation"—recurrent procedures used in many projects, project methodologies.

Two of them, $\mathrm{O} 2$ and O5, were mentioned only by a few authors and not in recent years. Concerning factors $\mathrm{O} 1, \mathrm{O} 3$ and especially $\mathrm{O} 6$ we found growing interest of authors in recent years. In the case of factor $\mathrm{O} 4$, we found that it was very often mentioned in the first five years of the studied period (almost 30\% of papers), then the interest of authors dropped to increase again after 2010.

Among product quality factors, the single most important and growing is E3 "compliance with scope", which was mentioned in $40 \%$ of papers in recent five years. The large group of factors 
encounters a constant level of interest: S1, D1, E1, E5, E6, E7. In the case of several factors (S2, S3, D2, D3, E2 and E4), we found only a little or no interest of researchers. These are again soft factors related to customer satisfaction during and after finishing the project.

\subsection{Relations between the Factors}

Apart from observing changes in quality factors in time, it is also interesting how authors see relations between them. The factors presented in Figure 6 are connected with lines of different thickness, which refers to how often they were studied together in one paper. Factors that were the most popular (F1 and E3) were also perceived by the largest number of authors (16 papers) as linked. Other important relations are F11-E3, F3-E3, F1-F11, S1-D1 (more than ten papers). That observation also confirms that compliance with the specification is the leading approach adopted by researchers.

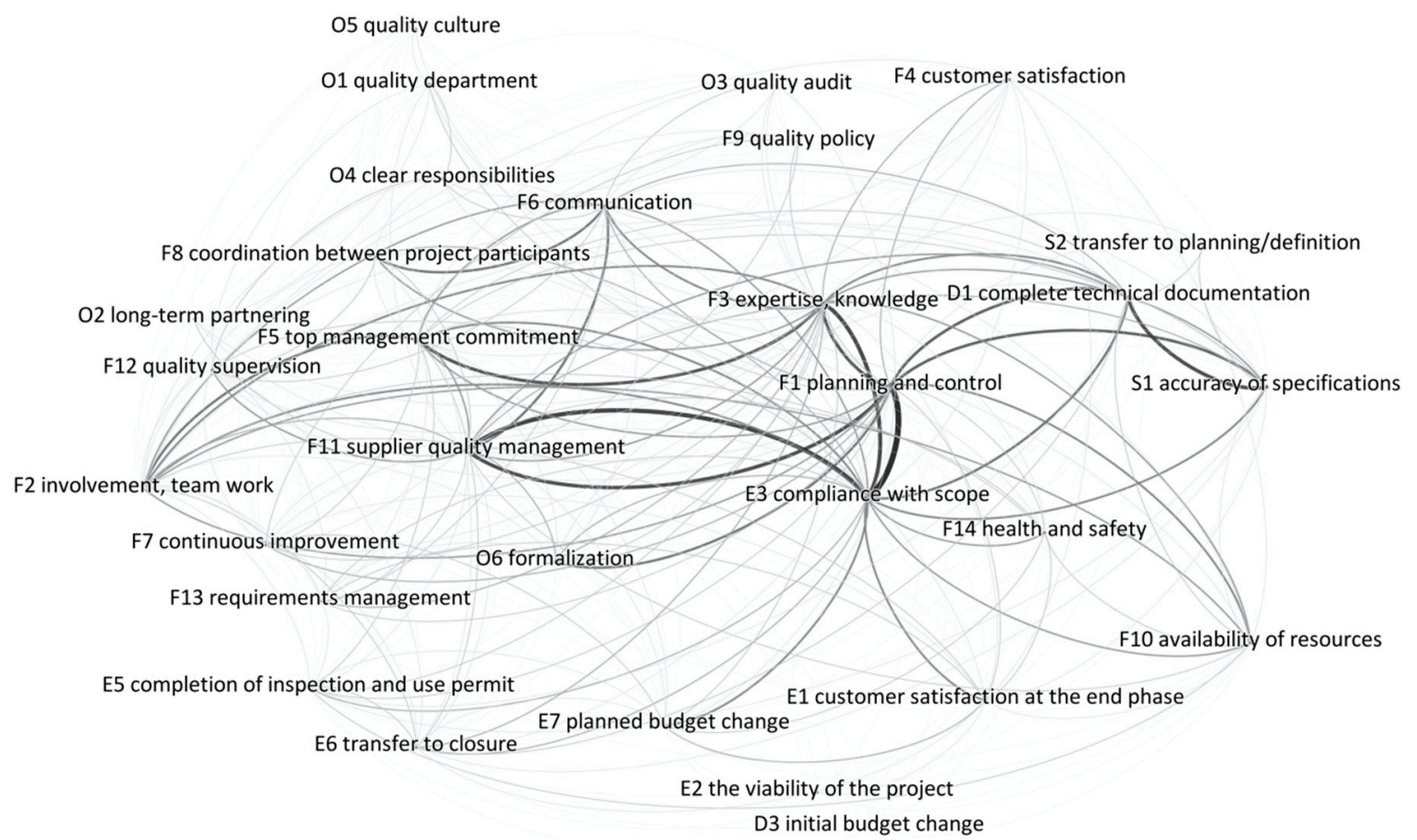

Figure 6. Relations between quality factors based on analysed papers. The thickness of lines means the number of papers with relation identified (max. 16-the thickest line). Source: research results.

\section{Discussion}

The analysis showed that a pattern related to the place of research is visible among the articles. The corpus consisted of articles written in English, which meant that most of the publications published before 2000 were in the US or Canada. In the last 20 years, publishing in English has become more popular in Europe and Asia, which is one of the reasons why more publications from these continents appeared between 2000 and 2019. However, that does not explain why the number of publications in North America dropped significantly after 2004 and the reason most publications in Australia were published between 2001 and 2004. That decline occurred at the same time as the general decline in interest in TQM [34]. The increase in English-language publications on quality in projects among European researchers mainly concerns Western Europe. Only four publications from recent years came from the countries of Central and Eastern Europe. It can, therefore, be assumed that it is associated with more frequent publication in English. In the case of Asia, the increase in the number of publications may also be due to the dynamic development of the construction industry and the implementation of modern project management methods that were already used in North America or Europe.

The quality-related factors are identified in the literature review within three groups (Table 3) covering quality management issues in construction projects. The most mentioned process quality 
factors are F1 "planning and control", F3 "expertise and knowledge", F11 "supplier quality management", and F6 "communication". O6 "formalisation", O4 "clear responsibilities" and O1 "quality department" are the most mentioned organisation quality factors. Most mentioned product quality factors are E3 "compliance with scope", S1 "accuracy of specifications", and D1 "complete technical documentation".

The previous study performed by authors analysed F1-F11 (Table 3) process factors, factor F8 "coordination between project participants" (investor, contractor, and project manager) ranked first [22]. The survey participants believe it is the most important, but it is not the most mentioned factor in analysed papers. Factor F4 "customer satisfaction" and F6 "communication" were mentioned in over 20 papers (e.g., $[35,36])$, and research showed that they are crucial for participants. The most mentioned factor in papers was F1 "planning and control", and it is ranked in fourth place in research. That can be because the survey participants do not see the importance and benefit of it in practice. Factor F11 "supplier quality management" was often mentioned in the papers, but in the research, the participants believe that it is not much important (last ranked). Meanwhile, the contractors believe that it is quite essential, and they ranked it in fourth place because they are in a direct link with suppliers, and supplier quality management is vital for their work.

The impact of the process quality factors on the quality of results is visible mostly during the planning and execution phases in a relatively short time. For example, wrong planning can lead to delays or excess tasks, while supplier quality management errors show up in deliveries non-compliant with the specification.

The organisation's quality factors were not analysed before, giving this study more significance. This study identified organisation factors in the SLR, long-term partnering and clear responsibilities are not often mentioned. This result can be linked to a change in the way projects are run in recent years. The link between all organisation quality factors and all process quality factors is essential (over 80 papers), showing the importance of understanding what links mean and which factors are most influential. The fewest links were found between F10 and organisational factors. The F10 "availability of resources" links only to the O6 "formalisation", which shows that depending on the availability of resources, it is possible to work on project methodologies.

Identified product factors (through the project life cycle): accuracy of specifications, transfer without errors and shortcomings, downtime, permits acquired, the difference between predicted and planned budgets, the viability of the project and the contribution for future projects are the least recognised in this study. That can be because these factors are more difficult to observe due to necessary contact with an investor, not only a construction company. That can also stem from a more narrow definition of quality, often used in the construction industry, as only compliance with the written specification and not the customer's soft expectations.

In the papers factor D1 "complete technical documentation" was mentioned by 13 authors, D2 "permits acquired" and D3 "difference between predicted and planned budgets" we found only in one paper. In practice, these factors are recognised as necessary for the planning phase, which was shown in the previous study. The survey participants (previous study) recognised process factor "customer satisfaction" as very significant in all project phases. For example, this factor (measured by the use of new processes, methods, or technologies) is for over $55 \%$ of participants very significant in the planning phase. Still, it is not found in this study for this phase. The factor E1 "customer satisfaction at the end of the phase" (construction object) in the execution phase is recognised in the literature in twelve papers, and that is because, in this phase, customer satisfaction is essential for its completion.

Graphical analysis of relationships between quality factors presented in Figure 6 helps to understand essential links and trace how authors of previous studies saw connections between them. However, that approach has some severe limitations. The relations can be observed and counted, but they may not explain the real-world issues well, as they stem from the meta-analysis. To overcome this limitation, a statistical, quantitative approach has to be applied. Therefore, the next step is defining a 
null SEM model, which shows links between the three groups of quality factors: quality of a process, quality of an organisation, and quality of the product (Figure 7, markings described in Table 3).

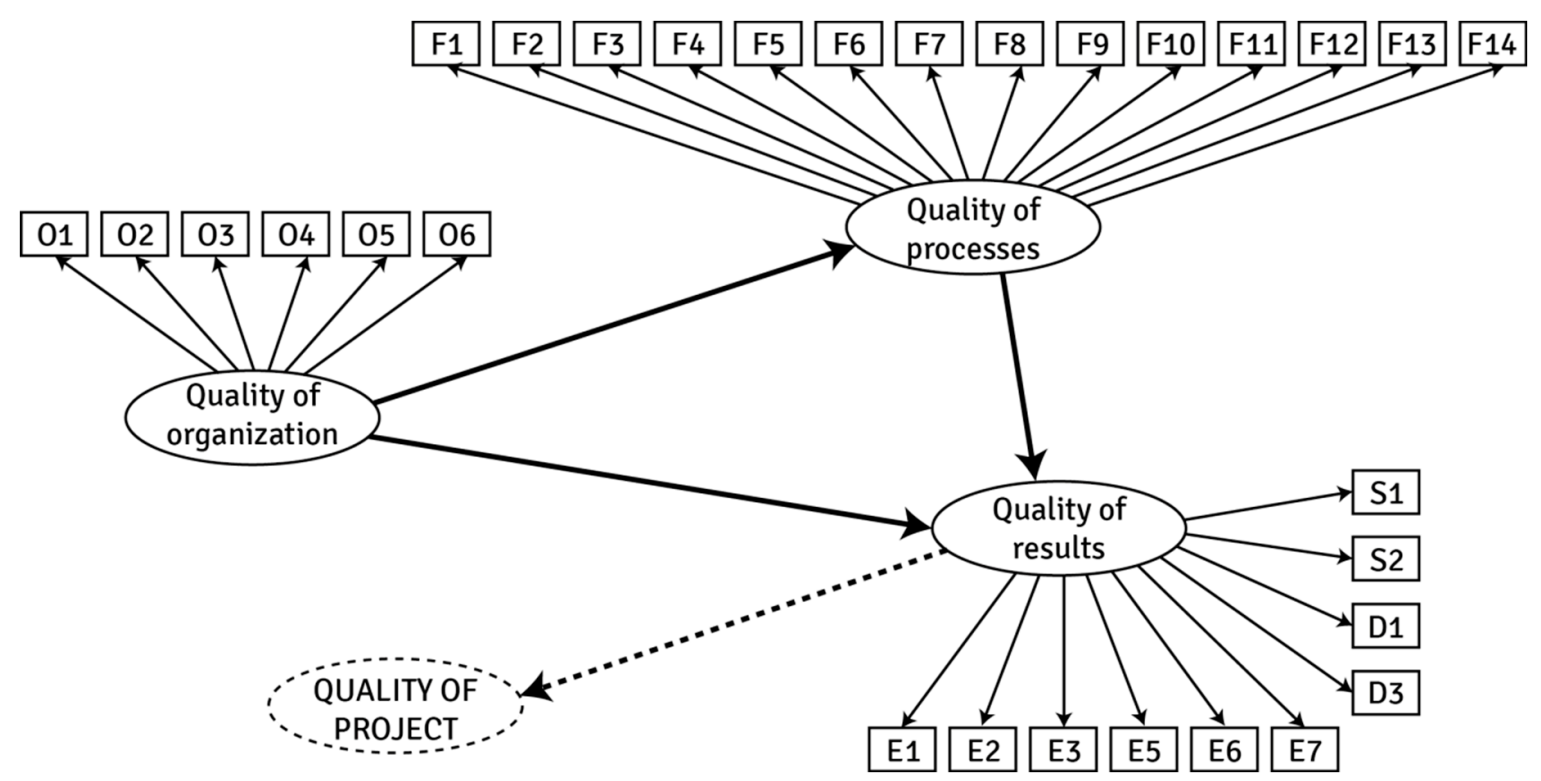

Figure 7. Null SEM model—the link between Quality of organisation, Quality of process, Quality of results. Source: research results.

The factor F1 "planning and control" is the most often mentioned in analysed papers, and its impact in the SEM model was found in the previous study as significant. The author's SEM model from the previous study showed that the factor D2 "permits acquired" in the quality of results is important, but it was not found in this SLR [28], and thus, it was not presented in the new null model. The other factors that were identified in the earlier stages of the research project, but not found in the SLR, were also excluded. Therefore, S3 "downtime", D2 "permits acquired", and E4 "contribution for future projects" were removed from the SEM model. To discover the real relationships and links between the process, organisation, and product-related quality factors and improve the presented null SEM model, it is necessary to perform the next steps of our research project. The comparison of results achieved in this study with previous ones leads to some insights. This study identified the quality-related factors in construction projects present in the literature and their grouping and constructed the preliminary null SEM model show assumed relations between groups of factors [28]. The new group was identified — quality factors related to the enterprise in which a project is executed (quality of organisation). In previous studies, it was found that the most significant impact on the quality of results had the quality of processes (found to be significant) [28]. In the next step, it is necessary to determine the impact of both quality of processes and quality of organisation on the quality of results and how new factors impact previous results. That will be achieved through a survey in construction enterprises in several European countries, and it will lead to the presentation of the final SEM model.

\section{Conclusions}

In this study, two objectives were defined: Construction of the preliminary model showing assumed relations between groups of factors and its comparison with the literature and previous studies. An SLR approach was applied to identify papers that covered identifying factors that impact quality management within construction project management.

After a two-stage screening process and following full-text analysis of papers, we selected 126 papers related to the topic, which allowed for a review of previously identified quality-related factors, supplementing them with newly found and creation of null SEM model for further research. We found no earlier SLR on that subject; therefore, the extended classification of the quality-related factors in 
construction projects is one of the significant results of this study. This study should help researchers and project managers, project sponsors, and steering committees. Knowledge of the quality-related factors and understanding of relations between them can significantly impact the ways the construction projects will be planned and executed.

Due to the advanced quantitative and qualitative analysis of the papers, we were able to track the evolution of the studies of quality-related factors in construction projects. We identified how the interest spread across continents and the main topics raised by researchers since the early nineties. The network analysis revealed relations between studied factors accepted and verified by authors of previous studies.

We identified three limitations of this study. Due to the limitation of academic databases, we limited the search to English-language papers only. Studies on that subject could be performed in other languages. We also hoped to find other approaches to the construction of the SEM model. Unfortunately, no attempts were found and we cannot compare our null model with other ones in this paper. The study was also limited due to the unavailability of 36 papers, which could enrich the conclusions.

This paper is part of a long-term project on quality in construction project management. In the next study, the authors plan to prepare and perform the survey in construction enterprises in several European countries. The results of that survey will be used to create the final SEM model, which will allow authors to present all significant links between the quality of organisation, quality of process, and quality of results.

Furthermore, the findings can be valuable to the current global associations such as Project Management Institute (PMI), International Project Management Association (IPMA), International Organization for Standardization (ISO) and similar when developing further their bodies of knowledge and process-based standards. Also, construction companies can use these results and the quality factors, presented in Appendix B when implementing their self-tailored project management methodologies or trying to align generic principle-based standards of managing construction projects, such as PMI's Construction Extension to the PMBoK Guide.

Although we have tried to grasp the quality story of project management processes holistically, we acknowledge that each theory or model might not be successful in any setting $[37,38]$. The field is just far too vast, occupying almost every industry. Creating a new or updating a current standard is a complicated and long term process, where it is arguable as to whether there is any such thing as a "best" solution. Still, we hope that both construction companies and project management professional bodies will find the results valuable in their future work.

Author Contributions: Conceptualisation, S.W., Ž.L., M.V.; methodology, S.W., Ž.L., M.V.; formal analysis, S.W.; investigation, Ž.L, M.V.; writing—original draft preparation, S.W., Ž.L.; writing—review and editing, S.W., Ž.L., M.V.; visualisation, S.W.; supervision, M.V.; project administration, S.W. All authors have read and agreed to the published version of the manuscript.

Funding: The publication was supported under Cracow University of Economics statutory research funding scheme.

Conflicts of Interest: The authors declare no conflict of interest.

\section{Appendix A List of Papers Used in The Analysis by Group and Category}

\section{Appendix A.1 Organisation Quality Management Related}

\section{Appendix A.1.1 Quality Culture}

Acikara, T., Kazaz, A., Ulubeyli, S. Evaluations of construction Project Participants' Attitudes toward Quality Management in Turkey. Procedia Engineering 2017, 196, 203-210.

Atkinson, A. Human error in the management of building projects. Construction Management and Economics 1998, 16(3), 339-349. 
Cheetham, D.W., Carter, D.J. The challenge of assuring quality on site British construction site quality assurance case study. Building Research \& Information 1993, 21(2), 85-98.

Collier, P., Corbett, M., Lundrigan, B. Quality performance in a design-build mega-project. Annual Quality congress Transactions 2001, 17-26.

Jawaharnesan, L., Price, ADF Assessment of the role of the client's representative for quality improvement. Total Quality Management 1997, 8(6), 375-389.

Lee, S.H., Peña-Mora, F. Understanding and managing iterative error and change cycles in construction. System Dynamics Review 2007, 23(1), 35-60.

Mahmood, W.Y.W., Mohammed, A.H. A conceptual framework for the development of quality culture in the construction industry. Proceedings of the 24th Annual conference. Association of Researchers in construction Management, 2008, 247-256.

Tang, S.L., Aoieong, R.T., Tsui, C.S.L. Quality Culture Auditing for construction Contractors. HKIE Transactions Hong Kong Institution of Engineers 2010, 17(1), 26-35.

Yng Ling, F.Y., Nga, Tran H. Undesirable project management practices adopted to achieve project outcomes a case study of Vietnam. International Journal of Project Organisation and Management 2012, $4(2), 153-170$.

Appendix A.1.2 Process vs. Organisation

Basu, R. Managing quality in projects: An empirical study. International Journal of Project Management 2014, 31(1), 178-187.

Wu, Y., Huang, Y., Zhang, S., Zhang, Y. Quality self-control and co-supervision mechanism of construction agent in public investment project in China. Habitat International 2012, 36(4), 471-480.

Appendix A.1.3 Design Phase

Abdul-Rahman, H., Rahim, F.A.M., Danuri, M.S.M., Wah, L.W. A study on quality management during the pre-construction stage of design-and-build projects. CME 2007 conference-Construction Management and Economics: 'Past, Present and Future' 2007, 753-764.

Anderson, S.D., Cook, E.L. TQM implementation strategy for capital projects. Journal of Management in Engineering 1995, 11(4), 39-47.

Chang, A.-P., Chou, C.-C., Lin, J.-D. To enhance quality control by using PDRI to define scope of project procurement. Journal of Quality 2014, 21(4), 269-282.

Chase, G.W., Federle, MOO Implementation of TQM in building design and construction. Journal of Management in Engineering 1992, 8(4), 329-339.

Fisher, D., Miertschin, S., Pollock, D.R., Jr. Benchmarking in construction industry. Journal of Management in Engineering 1995, 11(1), 50-57.

Kurdziel, J.M., Nelson, C.R., Nystrom, J.A., Peterson, D.L. Intelligent construction systems; the convergence of computing, communication, and construction. Joint conference on Water Resource Engineering and Water Resources Planning and Management 2000: Building Partnerships 2004.

Shen, Y.J., Walker, D.H.T. Integrating OHS, EMS and QM with constructability principles when construction planning-A design and construct project case study. TQM Magazine 2001, 13(4), 247-259. Toakley, A.R., Marosszeky, M. Towards total project quality-A review of research needs. Engineering, construction and Architectural Management 2003, 10(3), 219-228.

Appendix A.2 Quality Management System

Appendix A.2.1 QMS

Abdul-Rahman, H. Some observations on the management of quality among construction professionals in the UK. Construction Management and Economics 1996, 14(6), 485-495.

Battikha, M.G. QUALICON: Computer-based system for construction quality management. Journal of construction Engineering and Management 2002, 128(2), 164-173. 
Battikha, M.G., Russell, A.D. Construction quality management-Present and future. Canadian Journal of Civil Engineering 1998, 25(3), 401-411.

Burati, J.L., Jr., Matthews, M.F., Kalidindi, S.N. Quality management in construction industry. Journal of construction Engineering and Management 1991, 117(2), 341-359.

Chen, J., Yang, G. Stuty on improving quality management of construction by information technology. Applied Mechanics and Materials 2012, 174-177, 3471-3474.

Chileshe, N. PHD in construction management research: What is original contribution to knowledge? The case of TQM. In: Proceedings of the 21st Annual conference. Association of Researchers in construction Management, 2005, 1267-1278.

Chini, A.R., Valdez, H.E. ISO 9000 and the USS construction industry. Journal of Management in Engineering 2003, 19(2), 69-77.

Jiang, L., Chen, X., Zhang, X. Virtual organisation of construction project based on project life cycle. Communications in Computer and Information Science 2011, 209, 47-53.

Kiwus, C.H., Williams, T.P. Application of TQM to environmental construction. Journal of Management in Engineering 2001, 17(3), 176-184.

Lam, K.C., Ng, ST. A cooperative Internet-facilitated quality management environment for construction. Automation in construction 2006, 15(1), 1-11.

Leong, T.K., Zakuan, N., Saman, MZM Review of quality management system research in construction industry. International Journal of Productivity and Quality Management 2014, 13(1), 105-123.

Olafsdottir, A.H., Sverdrup, H., Stefansson, G., Ingason, H.T. Using system dynamics to better understand quality management in the construction industry. International Journal of Productivity and Quality Management 2019, 26(2), 223-245.

Pheng, L.S., Wee, D. Improving maintenance and reducing building defects through ISO 9000. Journal of Quality in Maintenance Engineering 2001, 7(1), 6-24.

Appendix A.2.2 QMS Implementation

Pheng, L.S., Teo, J.A. Implementing total quality management in construction firms. Journal of Management in Engineering 2004, 20(1), 8-15.

Rashed, A., Othman, M. Implementing quality management in construction projects. IEOM 2015-5th International conference on Industrial Engineering and Operations Management, Proceeding 2015.

Song, X.-H., Niu, D.-X., Ye, C.-Q., Lu, D.-L. Survey on the quality management system of power distribution projects based on the theory of TQM. Applied Mechanics and Materials 2012, 108, 30-34.

Appendix A.3 Satisfaction/Customer Satisfaction

Albert P.C. Chan, C.M. Tam Factors affecting the quality of building projects in Hong Kong. International Journal of Quality \& Reliability Management 2000, 17(4/5), 423-442.

Al-Momani, A.H. Examining service quality within construction processes. Technovation 2000, 20(11), 643-651.

Williams, P., Ashill, N.J., Naumann, E., Jackson, E. Relationship quality and satisfaction: Customerperceived success factors for on-time projects. International Journal of Project Management 2015, 33(8), 1836-1850.

Appendix A.4 Performance-Related

Appendix A.4.1 Performance

Arditi, D., Lee, D.-E. Assessing the corporate service quality performance of design-build contractors using quality function deployment. Construction Management and Economics 2003, 21(2), 175-185.

Bassioni, H.A., Price, A.D.F., Hassan, T.M. Performance measurement in construction. Journal of Management in Engineering 2004, 20(2), 42-50. 
Din, S., Abd-Hamid, Z., Bryde, D.J. ISO 9000 certification and construction project performance: The Malaysian experience. International Journal of Project Management 2011, 29(8), 1044-1056.

Haponava, T., Al-Jibouri, S. Influence of process performance during the construction stage on achieving end-project goals. Construction Management and Economics 2010, 28(8), 853-869.

$\mathrm{Ke}, \mathrm{H}$. , Yue, L., Hu, Z.P. Research on grading standard of the project quality management system under comprehensive evaluation method. Applied Mechanics and Materials 2014, 638-640, 2332-2337.

Ledbetter, W.B. Quality performance on successful project. Journal of construction Engineering and Management 1994, 120(1), 34-46.

Leong, T.K., Zakuan, N., Mat Saman, MZZ, Ariff, M.S.M., Tan, C.S. Using project performance to measure effectiveness of quality management system maintenance and practices in construction industry. The Scientific World Journal 2014, 591361.

Luu, V.T., Kim, S.-Y., Huynh, T.-A. Improving project management performance of large contractors using benchmarking approach. International Journal of Project Management 2008, 26(7), 758-769.

Miao, Y.H. Construction project quality evaluation system from lean construction perspective. Applied Mechanics and Materials 2014, 687-691, 4438-4441.

Olafsdottir, A.H., Ingason, H.T., Stefansson, G. Defining the variables for a dynamic model of quality management in the construction industry. Results from stakeholder group model-building sessions. International Journal of Productivity and Quality Management 2016, 19(2), 187-208.

Palaneeswaran, E., Ng, T., Kumaraswamy, M. Client satisfaction and quality management systems in contractor organisations. Building and Environment 2006, 41(11), 1557-1570.

Shanmugapriya, S., Subramanian, K. Structural equation model to investigate the factors influencing quality performance in Indian construction projects. Sadhana - Academy proceedings in Engineering Sciences 2015, 40(6), 1975-1987.

Stevens, J.D. Blueprint for measuring project quality. Journal of Management in Engineering 1996, 12(2), 34-39.

Zavadskas, E.K., Vilutienė, T., Turskis, Z., Šaparauskas, J. Multi-criteria analysis of Projects' performance in construction. Archives of Civil and Mechanical Engineering 2014, 14(1), 114-121.

Zulu, S. Impact of project management on project performance: A structural equation modelling approach. In: Proceedings of 23rd Annual ARCOM Conference, 2007, 651-660.

Appendix A.4.2 Critical Success Factors

Ceptureanu, E.-G., Ceptureanu, S.-I., Luchian, C.-E., Luchian, I. Quality management in project management consulting. A case study in an international consulting company. Amfiteatru Economic 2017, 19(44), 215-230.

Collins, A., Baccarini, D. Project success-A survey. Journal of construction Research 2004, 5(2), 211-231.

Doloi, H. Analysis of pre-qualification criteria in contractor selection and their impacts on project success. Construction Management and Economics 2009, 27(12), 1245-1263.

Kululanga, G.K., Kuotcha, W., McCaffer, R., Edum-Fotwe, F. Construction contractors' claim process framework. Journal of construction Engineering and Management 2001, 127(4), 309-314.

Rahman, H.A., Wang, C., Jackson, C. CTM 4 model using Ishikawa diagram for quality management in design-and-build projects. Scientific Research and Essays 2011, 6(25), 5442-5456.

Appendix A.4.3 Quality Factors

Chen, H.Z., Wu, A.J., Shen, L. Research on quality management system of Wuxi Taihu international expo center project. Applied Mechanics and Materials 2012, 226-228, 2268-2272.

Hamzah, N., Ramly, A., Salleh, H., Tawil, N.M., Khoiry, M.A., Che Ani, AI. The importance of design process in housing quality. Procedia Engineering 2011, 20, 483-489.

Yung, P. Yip, B. Construction quality in China during transition: A review of literature and empirical examination. International Journal of Project Management 2010, 28(1), 79-91. 
Appendix A.4.4 Costs of Quality

Al-Tmeemy, S.M.H., Rahman, H.A., Harun, Z. Contractors' perception of the use of costs of quality system in Malaysian building construction projects. International Journal of Project Management 2012, 30(7), 827-838.

Duttenhoeffer, R. Cost and quality management. Journal of Management in Engineering 1992, 8(2), 167-175. Hall, M., Tomkins, C. A cost of quality analysis of building project: Towards a complete methodology for design and build. Construction Management and Economics 2001, 19(7), 727-740.

Mashwama, N., Aigbavboa, C., Thwala, D. An Assessment of the Critical Success factor for the Reduction of Cost of Poor Quality in construction Projects in Swaziland. Procedia Engineering 2017, 196, 447-453.

Pollack-Johnson, B., Liberatore, M.J. Incorporating quality considerations into project time/cost tradeoff analysis and decision making. IEEE Transactions on Engineering Management 2006, 53(4), 534-542.

Rounce, G. Quality, waste and cost considerations in architectural building design management. International Journal of Project Management 1998, 16(2), 123-127.

Shao, B., Wang, F., Chen, Z. Research on applying the total quality management to implicit cost control in construction projects. Advanced Materials Research 2012, 368-373, 3150-3154.

Tam, V.W.Y., Le, K.N. Quality improvement in construction by using a Vandermonde interpolation technique. International Journal of Project Management 2007, 25(8), 815-823.

Tang, S.L., Aoieong, R.T., Ahmed, S.M. The use of Process Cost Model (PCM) for measuring quality costs of construction projects: Model testing. Construction Management and Economics 2004, 22(3), 263-275.

Titov, S., Nikulchev, E., Bubnov, G. Learning Practices as a Tool for Quality Costs Reduction in construction Projects. Quality—Access to Success 2015, 16(149), 68-70.

Appendix A.5 Quality Assurance Related

Appendix A.5.1 Improvement

Kazaz, A., Birgonul, M.T. The evidence of poor quality in high rise and medium rise housing units: A case study of mass housing projects in Turkey. Building and Environment 2005, 40(11), 1548-1556.

McNary, L.D. Quality management in the public services department of a city government: Streamlining the street cave-in repair process. Quality Engineering 2001, 13(3), 485-500.

Nyborg, A., Bjorlo, A. Hibernia GBS: construction schedule recovery applying total quality management principles. Proceedings of the Annual Offshore Technology conference 1997, 2, 8399.

Soares, J., Anderson, S. Modeling process management in construction. Journal of Management in Engineering 1997, 13(5), 45-53.

Stewart, R.A., Spencer, C.A. Six-sigma as a strategy for process improvement on construction projects: A case study. Construction Management and Economics 2006, 24(4), 339-348.

Appendix A.5.2 Quality Inspection

Al-Ani, R., Al-Adhmawi, F.I. Implementation of quality management concepts in managing engineering project site. Jordan Journal of Civil Engineering 2011, 5(1), 89-106.

Hedayatnasab, A., Majrouhisardroud, J., Limbachiya, M. Improving construction quality control and management using automated data collection technologies. IMCIC 2011-2nd International Multi-conference on Complexity, Informatics and Cybernetics, proceedings 2011, 24-29.

Kraft, E., Molenaar, K. Fundamental project quality assurance organisations in highway design and construction. Journal of Management in Engineering 2014, 30(4), 04014015.

Leu, S.-S., Tzeng, B.-R. A CPM-based construction quality inspection and decision-aid system. Computer-Aided Civil and Infrastructure Engineering 2000, 15(3), 233-239. 
Minchin, R.E., Hammons, M.I., Ahn, J. A construction quality index for highway construction. Construction Management and Economics 2008, 26(12), 1313-1324.

Appendix A.5.3 Rework

Balouchi, M., Gholhaki, M., Niousha, A. Reworks causes and related costs in construction: case of Parand mass housing project in Iran. International Journal of Quality and Reliability Management 2019, 36(8), 1392-1408.

Josephson, P.-E., Larsson, B., Li, H. Illustrative benchmarking rework and rework costs in Swedish construction industry. Journal of Management in Engineering 2002, 18(2), 76-83.

Love, P.E.D., Smith, J. Benchmarking, benchaction, and benchlearning: Rework mitigation in projects. Journal of Management in Engineering 2003, 19(4), 147-159.

Appendix A.5.4 BIM

Gökçe, K.U., Scherer, R.J., Dikbas, H.A. Integrated construction project management system based on IFC and ISO 9001:2000. IFIP International Federation for Information Processing 2007, 243, 513-520.

Ma, Z., Cai, S., Mao, N., Yang, Q., Feng, J., Wang, P. Construction quality management based on a collaborative system using BIM and indoor positioning. Automation in construction 2018, 92, 35-45.

Nguyen, P.T., Vo, K.D., Phan, P.T., Huynh, V.D.B., Nguyen, T.A., Cao, T.M., Nguyen, QLHTT, Le, L.P. Construction project quality management using building information modeling 360 field. International Journal of Advanced Computer Science and Applications 2018, 9(10), 228-233.

Pasquire, C., Pennanen, A., Ballard, G., Haahtela, Y. Target costing and designing to targets in construction. Journal of Financial Management of Property and construction 2011, 16(1), 52-63.

Stransky, M., Matejka, P. Digital quality management in construction industry within BIM projects. Engineering for Rural Development 2019, 18, 1707-1718.

Wang, K.-C., Wang, S.-H., Kung, C.-J., Weng, S.-W., Wang, W.-C. Applying BIM and visualisation techniques to support construction quality management for soil and water conservation construction projects. 35th International Symposium on Automation and Robotics in construction and International AEC/FM Hackathon: The Future of Building Things. ISARC, 2018.

Appendix A.6 External Relations

Appendix A.6.1 Procurement

Dozzi, P., Hartman, F., Tidsbury, N., Ashrafi, R. More-stable owner-contractor relationships. Journal of construction Engineering and Management 1996, 122(1), 30-35.

Erickson, J. Meeting the quality management issue on highway construction. Journal of Professional Issues in Engineering Education and Practice 1989, 115(2), 162-167.

Gransberg, D.D., Molenaar, K. Analysis of owner's design and construction quality management approaches in design/build projects. Journal of Management in Engineering 2004, 20(4), 162-169.

Molenaar, K.R., Bogus, S.M., Priestley, J.M. Design/build for water/wastewater facilities: State of the industry survey and three case studies. Journal of Management in Engineering 2004, 20(1), 16-24.

Pongpeng, J., Liston, J. Constractor ability criteria: A view from the Thai construction industry. Construction Management and Economics 2003, 21(3), 267-282.

Yean Yng Ling, F. Models for predicting quality of building projects. Engineering, construction and Architectural Management 2005, 12(1), 6-20.

Appendix A.6.2 Partnering

Gransberg, D.D., Dillon, W.D., Reynolds, L., Boyd, J. Quantitative analysis of partnered project performance. Journal of construction Engineering and Management 1999, 125(3), 161-166. 
Tang, W., Duffield, C.F., Young, D.M. Partnering mechanism in construction: An empirical study on the chinese construction industry. Journal of construction Engineering and Management 2006, 132(3), 217-229. Tang, W., Qiang, M., Duffield, C.F., Young, D.M., Lu, Y. Enhancing total quality management by partnering in construction. Journal of Professional Issues in Engineering Education and Practice 2009, 135(4), 129-141.

Wilson, R.A., Jr., Songer, A.D., Diekmann, J. Partnering More than a workshop, a catalyst for change. Journal of Management in Engineering 1995, 11(5), 40-45.

Appendix A.6.3 Suppliers QM

AlMaian, R.Y., Needy, K.L., Walsh, K.D., Alves, TDCL. A qualitative data analysis for supplier quality-management practices for engineer-procure-construct projects. Journal of construction Engineering and Management 2016, 142(2), 04015061.

Koch, C., Larsen, C.S. Quality in construction: A supply chain perspective. In: Proceedings 22nd Annual ARCOM conference. Association of Researchers in construction Management, 2006, 459-469.

Yousef, R., La Scola Needy, K., Walsh, K.D., Da Alves, T.C.L. Supplier quality management inside and outside the construction industry. EMJ - Engineering Management Journal 2015, 27(1), 11-22.

Yu, T., Man, Q., Wang, Y., Shen, G.Q., Hong, J., Zhang, J., Zhong, J. Evaluating different stakeholder impacts on the occurrence of quality defects in offsite construction projects A Bayesian-network-based model. Journal of Cleaner Production 2019, 241, 118390.

Zeng, S.X.X., Lou, G.X., Tam, V.W.Y. Managing information flows for quality improvement of projects. Measuring Business Excellence 2007, 11(3), 30-40.

Appendix A.7 Other Management Systems

Appendix A.7.1 Environment

Khadour, L., Darkwa, J. TQEM in the UK construction industry: Some key findings from a survey. In: Proceedings of the 24th Annual conference. Association of Researchers in construction Management 2008, 239-246.

Khadour, L., Ramsay-Dawber, P., Morledge, R. Case studies on the implementation of TQEM in the UK building contractors. Proceedings of the 25th Annual conference. Association of Researchers in construction Management, 2009, 1051-1058.

Appendix A.7.2 Safety

Loushine, T.W., Hoonakker, P.L.T., Carayon, P., Smith, M.J. Quality and Safety Management in construction. Total Quality Management 2006, 17(9), 1171-1212.

Ogwueleka, A.C. A Review of Safety and Quality Issues in the construction Industry. Journal of construction Engineering and Project Management 2013, 3(3), 42-50.

Husrul, N.H., Hamimah, A., Kamaruzaman, J. Management of Safety for Quality construction. Journal of Sustainable Development 2008, 1(3), 41-47.

Appendix A.8 Methods

Basu, R. Quality management tools and techniques in major infra-structure projects. 2017 6th International conference on Reliability, Infocom Technologies and Optimisation: Trends and Future Directions 2018, 114-126.

Delgado-Hernandez, D.J., Aspinwall E. A framework for building quality into construction projects Part I. Total Quality Management 2008, 19(10), 1013-1028.

Delgado-Hernandez, D.J., Aspinwall, E.M. Improvement tools in the UK construction industry. Construction Management and Economics 2005, 23(9), 965-977.

Delgado-Hernandez, D.J., Bampton, K.E., Aspinwall, E. Quality function deployment in construction. Construction Management and Economics 2007, 25(6), 597-609. 
Delgado-Hernandez, D.J., Cruz-Cruz, C.C., Vences-García, P.Y. Improvement Management Tools in the construction Industry: Case Study of Mexico. Journal of construction Engineering and Management 2017, 143(4), 05016024.

Halpin, D.W., Kueckmann, M. Lean construction and simulation. Winter Simulation conference proceedings 2002, 1697-1703.

Jia, W. Application of quality control techniques in construction projects. Advanced Materials Research 2012, 433-440, 1513-1518.

Page, W.A., Teague, R.D. Mobile Bay Project quality management program. Proceedings of the Annual Offshore Technology conference 1994, 287-296.

Ren, M.-M., Ling, N., Wei, X., Fan, S.-H. The application of PDCA cycle management in project management. International conference on Computer Science and Applications 2017, 268-272.

$\mathrm{Su}$, Z.G. Research on construction quality control content and method. Applied Mechanics and Materials 2014, 687-691, 4511-4514.

Appendix A.9 Others (Without a Category)

Keeling, D. Channel Tunnel Rail Link Quality management. Proceedings of the Institution of Civil Engineers: Civil Engineering 2003.

Liu, A.M.M. The quest for quality in public housing projects: A behaviour-to-outcome paradigm. Construction Management and Economics 2003, 21(2), 147-158.

Love, P.E.D., Josephson, P.-E. Role of error-recovery process in projects. Journal of Management in Engineering 2004, 20(2), 70-79.

Pheng, L.S., Hong, S.H. Strategic quality management for the construction industry. TQM Magazine 2005, 17(1), 35-53.

Walker, D.H.T., Keniger, M. Quality management in construction: An innovative advance using project alliancing in Australia. TQM Magazine 2002, 14(5), 307-317.

\section{Appendix B Interpretation of Quality-Related Factors}

Appendix B.1 Process Quality Factors

- $\quad$ F1 Planning and control—use of methods, techniques, and technologies for planning and control in project implementation;

- F2 Involvement and teamwork-project participants involved in the project, and an efficient team;

- F3 Expertise and knowledge-people involved in the project are qualified, possess competencies, know and apply techniques, methods for the work they perform;

- F4 Customer satisfaction-focus on understanding and customer expectations and fulfilling them;

- F5 Top management commitment-managers available, responsible and involved in the project, contribute to the quality;

- F6 Communication-effective transmission of information, lack of misunderstanding, conflict management;

- $\quad$ F7 Continuous improvement-effects of improvement visible in the project, employees involved in the implementation of new methods or technologies;

- F8 Coordination between project participants-work performed by different contractors or employees is coordinated in time;

- $\quad$ F9 Quality policy—the formal quality policy was described and implemented; employees act according to the policy;

- F10 Availability of resources-resources are well planned, controlled and adequately utilised;

- F11 Supplier quality management-quality management practices extend to suppliers, including at least supplies control and effective information exchange; 
- F12 Quality supervision— team members were assigned to monitor and control quality; quality monitoring procedures are present;

- F13 Requirements management-elicitation, documentation, change management, configuration management.

- $\quad$ F14 Health and safety—team members were assigned to monitor health and safety; H\&S procedures present and implemented; absence of unsafe behaviours among employees;

Appendix B.2 Organisation Quality Factors

- O1 Quality department-a permanent department in the organisation that coordinates quality management throughout the company and projects;

- O2 Long-term partnering-cooperation with suppliers and partners is not limited to one project only, but it is based on long-term relations, which allows continuous improvement;

- O3 Quality audit—quality management system is regularly monitored; quality audits results in change requests;

- O4 Clear responsibilities—-the responsibilities of all employees in the organisation and project are precisely described and well known;

- O5 Quality culture-pro-quality attitude is present among managers and employees even before the project begins.

- O6 Formalisation-all quality-related processes are described in procedures or other documentation; employees act according to the documentation; document change management process implemented;

Appendix B.3 Product Quality Factors

Phase 1. Initiation

- S1 Accuracy of specifications-initial specifications are precise and accurate;

- S2 Transfer without errors and shortcomings-no rework or delays during transfer between phases;

- S3 Downtime- the downtime, if necessary, is planned and optimised (e.g., brownfield projects);

\section{Phase 2. Planning}

- D1 Complete technical documentation-documentation includes all necessary information and takes into account known limitations (e.g., space, technology, resources);

- D2 Permits acquired-all permits before the execution phase acquired on time;

- D3 Difference between predicted and planned budgets-planned over-budget not higher than admissible by project management frameworks;

Phase 3. Execution

- E1 Customer satisfaction at the end phase-the delivered result consistent with customer requirements;

- E2 The viability of the project - the profitability of the project is consistent with the initial assumptions;

- E3 Compliance with scope - the project delivered according to time, cost and scope;

- E4 Contribution for future projects-good practices and lessons learned can be transferred to the organisation or the following projects;

- E5 Completion of inspection and use permit-all permits after the execution phase acquired on time;

- E6 Transfer without errors and shortcomings-no rework or delays during the transfer of the final result;

- E7 Initial budget change-final over-budget not higher than admissible by project management frameworks; 


\section{References}

1. Standish Group. The Standish Group Report Chaos; Standish Group International Inc.: Boston, MA, USA, 2018.

2. AXELOS. Managing Successful Projects with PRINCE2 ${ }^{\circledR}$, 6th ed.; TSO: London, UK, 2017; ISBN 978-0-11-331533-8.

3. AXELOS. Managing Successful Programmes; TSO: London, UK, 2020; ISBN 978-0-11-331676-2.

4. Project Management Institute. Construction Extension to the PMBOK Guide; Project Management Institute: Newtown Square, PA, USA, 2016; ISBN 978-1-62825-090-9.

5. Morris, P.W.G. Reconstructing Project Management; Wiley-Blackwell: Hoboken, NJ, USA, 2013; ISBN 978-1118-53691-9.

6. Svejvig, P.; Andersen, P. Rethinking project management: A structured literature review with a critical look at the brave new world. Int. J. Proj. Manag. 2015, 33, 278-290. [CrossRef]

7. Brocke, J.v.; Lippe, S. Managing collaborative research projects: A synthesis of project management literature and directives for future research. Int. J. Proj. Manag. 2015, 33, 1022-1039. [CrossRef]

8. Picciotto, R. Towards a 'New Project Management' movement? An international development perspective. Int. J. Proj. Manag. 2020, 38, 474-485. [CrossRef]

9. Bergmann, T.; Karwowski, W. Agile project management and project success: A literature review. In Advances in Human Factors, Business Management and Society; Kantola, J.I., Nazir, S., Barath, T., Eds.; Springer: Cham, Switzerland, 2019; Volume 783, pp. 405-414. ISBN 978-3-319-94708-2.

10. Olafsdottir, A.H.; Ingason, H.T.; Stefansson, G. Defining the variables for a dynamic model of quality management in the construction industry: Results from stakeholder group model-building sessions. Int. J. Prod. Qual. Manag. 2016, 19, 187. [CrossRef]

11. Ingason, H.; Olafsdottir, A.H.; Sverdrup, H.; Stefansson, G. Using system dynamics to better understand quality management in the construction industry. Int. J. Prod. Qual. Manag. 2019, 26, 1. [CrossRef]

12. Ren, M.-M.; Ling, N.; Wei, X.; Fan, S.-H. The application of PDCA cycle management in project management. In Proceedings of the 2015 International Conference on Computer Science and Applications (CSA), Wuhan, China, 20-22 November 2015; pp. 268-272.

13. Mashwama, N.; Aigbavboa, C.; Thwala, D. An assessment of the critical success factor for the reduction of cost of poor quality in construction projects in Swaziland. Procedia Eng. 2017, 196, 447-453. [CrossRef]

14. Watt, A. Project Management; BCampus: Victoria, BC, USA, 2014; ISBN 978-1-77420-013-1.

15. Basu, R. Managing quality in projects: An empirical study. Int. J. Proj. Manag. 2014, 32, 178-187. [CrossRef]

16. Dolaček-Alduk, Z.; Mikulić, D.; Radujković, M. Quality management in project-oriented construction processes. Građevinar 2007, 59, 209-218.

17. Ogwueleka, A.C. A review of safety and quality issues in the construction industry. J. Constr. Eng. Proj. Manag. 2013, 3, 42-48. [CrossRef]

18. Doskočil, R.; Lacko, B. Risk Management and knowledge management as critical success factors of sustainability projects. Sustainability 2018, 10, 1438. [CrossRef]

19. Wu, X.; Zhao, W.; Ma, T. Improving the impact of green construction management on the quality of highway engineering projects. Sustainability 2019, 11, 1895. [CrossRef]

20. Wang, G.; Liu, H.; Li, H.; Luo, X.; Liu, J. A building project-based industrialised construction maturity model involving organisational enablers: A multi-case study in China. Sustainability 2020, 12, 4029. [CrossRef]

21. Vukomanovic, M.; Radujkovic, M.; Nahod, M.M. EFQM excellence model as the TQM model of the construction industry of South-eastern Europe. J. Civ. Eng. Manag. 2014, 20, 70-81. [CrossRef]

22. Ljevo, Ž.; Vukomanović, M.; Džebo, S. Assessing the influence of project management on quality during the early phases of construction projects. Organ. Technol. Manag. Constr. 2018, 9, 1584-1592. [CrossRef]

23. Biedenbach, T.; Müller, R. Paradigms in project management research: Examples from 15 years of IRNOP conferences. Int. J. Manag. Proj. Bus. 2011, 4, 82-104. [CrossRef]

24. Fink, A. Conducting Research Literature Reviews: From Paper to the Internet; SAGE Publications: Thousand Oaks, CA, USA, 1998; ISBN 978-0-7619-0904-0.

25. Denyer, D.; Tranfield, D. Producing a systematic review. In The Sage Handbook of Organizational Research Methods; Buchanan, D.A., Bryman, A., Eds.; SAGE Publications: Thousand Oaks, CA, USA, 2009; pp. 671-689. ISBN 978-1-4129-3118-2.

26. Denyer, D.; Tranfield, D.; van Aken, J.E. Developing design propositions through research synthesis. Organ. Stud. 2008, 29, 393-413. [CrossRef] 
27. Moher, D.; Liberati, A.; Tetzlaff, J.; Altman, D.G. The PRISMA group preferred reporting items for systematic reviews and meta-analyses: The PRISMA statement. PLoS Med. 2009, 6, e1000097. [CrossRef]

28. Ljevo, Z.; Vukomanović, M.; Rustempašić, N. Analysing significance of key quality factors for management of construction projects. Građevinar 2017, 2017, 359-366. [CrossRef]

29. Byrne, B.M. Structural Equation Modeling with AMOS: Basic Concepts, Applications, and Programming, 3rd ed.; Lawrence Erlbaum Associates: Mahwah, NJ, USA, 2016; ISBN 978-1-138-79702-4.

30. Hair, J.F., Jr.; Anderson, R.E.; Tatham, R.L.; Black, W.C. Multivariate Data Analysis; Prentice Hall: Upper Saddle River, NJ, USA, 1998; ISBN 978-0-13-813263-7.

31. Hussain, S.; Fangwei, Z.; Siddiqi, A.; Ali, Z.; Shabbir, M. Structural equation model for evaluating factors affecting quality of social infrastructure projects. Sustainability 2018, 10, 1415. [CrossRef]

32. Kitchenham, B.; Charters, S. Guidelines for Performing Systematic Literature Reviews in Software Engineering; Keele University: Keele, UK; Durham University: Durham, UK, 2007.

33. Project Management Institute. A Guide to the Project Management Body of Knowledge, 6th ed.; Project Management Institute: Newton Square, PA, USA, 2017; ISBN 978-1-62825-184-5.

34. Wawak, S.; Rogala, P.; Dahlgaard-Park, S.M. Research trends in quality management in years 2000-2019. Int. J. Qual. Serv. Sci. 2020. [CrossRef]

35. Ceptureanu, E.-G.; Ceptureanu, S.-I.; Luchian, C.-E.; Luchian, I. Quality management in project management consulting. A case study in an international consulting company. Amfiteatru Econ. J. 2017, 19, 215.

36. Acıkara, T.; Kazaz, A.; Ulubeyli, S. Evaluations of construction project participants' attitudes toward quality management in Turkey. Procedia Eng. 2017, 196, 203-210. [CrossRef]

37. Koskela, L.J.; Howell, G. The underlying theory of project management is obsolete. In Proceedings of the PMI Research Conference (PMI), Seattle, WA, USA, 14-17 July 2002; pp. 293-302.

38. Melgrati, A.; Damiani, M. Rethinking the project management framework: New epistemology, new insights. In Proceedings of the PMI Research Conference (PMI), Seattle, WA, USA, 14-17 July 2002; pp. 371-380.

Publisher's Note: MDPI stays neutral with regard to jurisdictional claims in published maps and institutional affiliations.

(C) 2020 by the authors. Licensee MDPI, Basel, Switzerland. This article is an open access article distributed under the terms and conditions of the Creative Commons Attribution (CC BY) license (http://creativecommons.org/licenses/by/4.0/). 